\title{
Genetic diversity and structure of the vulnerable species Prosopis chilensis (Molina) Stuntz in the Coquimbo Region, Chile
}

\section{Diversidad y estructura genética de la especie vulnerable Prosopis chilensis (Molina) Stuntz en la Región de Coquimbo, Chile}

\author{
Ximena Moncada ${ }^{1,2 *}$, Daniel Plaza ${ }^{1}$, Alexandra Stoll ${ }^{1}$, Claudia Payacan ${ }^{3}$, Daniela Seelenfreund ${ }^{3}$, \\ Enrique Martínez ${ }^{1,4}$, Angéline Bertin ${ }^{5}$ \& Francisco A. SqueO $1,2,5$ \\ ${ }^{1}$ Centro de Estudios Avanzados en Zonas Áridas (CEAZA), Campus Andrés Bello, Universidad de La Serena, La Serena, \\ Chile. \\ ${ }^{2}$ Instituto de Ecología y Biodiversidad (IEB), Facultad de Ciencias, Universidad de Chile, Casilla 653, Santiago, Chile. \\ ${ }^{3}$ Departamento de Bioquímica y Biología Molecular, Facultad de Ciencias Químicas y Farmacéuticas, Universidad de Chile \\ ${ }^{4} \mathrm{PhD}$ Program of Applied Biology and Ecology, Facultad de Ciencias del Mar, Universidad Católica del Norte, Coquimbo, Chile. \\ ${ }^{5}$ Departamento de Biología, Facultad de Ciencias, Universidad de La Serena, Benavente 980, Casilla 554, La Serena, Chile. \\ *xmoncada@gmail.com
}

\begin{abstract}
The Prosopis genus (Mimosoideae, Leguminosae) constitutes an important genetic resource for arid and semiarid environments. Prosopis chilensis (Molina) Stuntz is a multipurpose species native to South America, which displays high phenotypic variability. In Chile, this species grows in the semiarid region, along river beds of the transverse valleys. We studied the genetic diversity and population genetic structure of $P$. chilensis across the three transverse valleys of the Coquimbo Region $\left(29^{\circ}-32^{\circ} \mathrm{S}\right)$ by analysing the genetic diversity of 182 individuals with four nuclear and one chloroplast microsatellite markers. Using a spatial principal component analysis (sPCA), we detected a clear hierarchical genetic structure. This analysis revealed the existence of seven distinct genetic clusters throughout the whole studied region. None of the genetic clusters detected overlapped between valleys. This suggests that the mountain ridges separating the three transverse valleys may have exerted a barrier effect. However, while significant, population differentiation was low and most of the genetic variation was found within clusters. These results suggest that high gene flow might be counteracting and blurring the effects of the structuring factors. This is the first study of genetic population of $P$. chilensis in Chile and the genetic data obtained may be valuable for the conservation of this vulnerable, multipurpose tree species.
\end{abstract}

KEYwords: Arid zones, biodiversity, microsatellites, transverse valleys, spatial principal component analysis (sPCA).

\section{RESUMEN}

El género Prosopis (Mimosoideae, Leguminosae) constituye un importante recurso genético de ambientes áridos y semiáridos. Prosopis chilensis (Molina) Stuntz es una especie multipropósito nativa de América del Sur que presenta una gran variabilidad fenotípica. En Chile, esta especie crece en la región semiárida, a lo largo de lechos de ríos de los valles transversales. En este trabajo se estudió la diversidad genética y la estructura genética de poblaciones de $P$. chilensis en los tres valles transversales de la Región de Coquimbo $\left(29^{\circ}-32^{\circ} \mathrm{S}\right)$ mediante un análisis de diversidad genética de 182 individuos con cuatro marcadores de microsatélites nucleares y uno de cloroplasto. Utilizando un análisis espacial de componentes principales (sPCA), se detectó una clara estructura genética jerárquica. Este análisis reveló la existencia de siete grupos genéticos distintos en la región estudiada. Ninguno de los grupos genéticos detectados se superpuso entre los valles. Esto sugiere que las cadenas montañosas que separan los tres valles transversales pueden haber ejercido un efecto de barrera. Sin embargo, aunque significativa, la diferenciación genética de la población fue baja y la mayor parte de la variación genética se encontró dentro de los grupos. Estos resultados sugieren que un alto flujo génico podría estar contrarrestando y desdibujando el efecto de factores de estructuramiento. Este es el primer estudio de genética de poblaciones en $P$. chilensis en Chile y los datos genéticos obtenidos pueden ser de utilidad para la conservación de esta especie arbórea vulnerable y multipropósito.

Palabras clave: Zonas áridas, biodiversidad, microsatélites, valles transversales, análisis espacial de componentes principales (sPCA). 


\section{INTRODUCTION}

The genus Prosopis (Mimosoideae, Leguminosae) was described by Burkart (1976a, b) and comprises 44 species. Its native distribution range includes three continents, with 40 species found solely in America (Hunziker et al. 1986, Pasiecznik et al. 2001). This genus contains trees and shrubs that are valuable genetic resources for arid and semiarid regions. Trees are mainly harvested for pods, fuel or timber and considered useful both for production purposes and environmental conservation initiatives, including institutional propagation plans (Pasiecznik et al. 2001).

One of the species of this genus with great value as a multipurpose tree is Prosopis chilensis (Molina) Stuntz (Verzino et al. 2003). This species is native to South America and its present distribution includes Peru, Bolivia, Paraguay, Argentina, and Chile (Galera 2000). In Argentina, P. chilensis grows naturally between $25^{\circ}-34^{\circ} \mathrm{S}$ (Verzino et al. 2003) and displays high phenotypic diversity and low differentiation between populations (Galera 2000, Verzino et al. 2003). Ferreyra et al. (2010) used RAPD and isozyme markers to study genetic diversity and population structure of $P$. chilensis in Argentina, and found that the expected heterozygosity varied significantly among populations and regions.

In Chile, P. chilensis (algarrobo) grows in the northern and central zones between $28^{\circ}-33^{\circ} \mathrm{S}$ (Galera 2000), thriving along dry watercourses and river beds in the foothills of the transverse valleys. The transverse valleys correspond to Andean-coastal mountainous systems found from the south of the Copiapó river valley $\left(27^{\circ} \mathrm{S}\right)$ to the Chacabuco range $\left(33^{\circ} \mathrm{S}\right)$, covering approximately $600 \mathrm{~km}$ and occupying a $50 \mathrm{~km}$ E-W wide strip. These disconnected valleys were formed by the uplifting of the Andes about 8.5 million years ago (Farías et al. 2008). The distinguishing orographic characteristic of these valleys is their E-W orientation, limited by mountains ranging between $600-1,000 \mathrm{~m}$ of altitude, without a homogeneous pattern, and transversal respect to the north-south Andean mountain range (Errázuriz et al. 1998). In addition, the transverse valleys present a north-south rainfall gradient (Westphal 2016). The main extension of the transverse valleys includes the Elqui, Limarí and Choapa valleys. These three valleys are located in the Coquimbo region (an administrative section of Chile between $29^{\circ}$ and $32^{\circ} \mathrm{S}$ ), which is the most southern part of the Atacama Desert (Squeo et al. 2001a) and are associated geomorphologically with a marked biogeographic discontinuity around $30^{\circ} \mathrm{S}$ (Villagrán \& Hinojosa 1997, Squeo et al. 2001a).

In spite of the importance of $P$. chilensis as a multipurpose species in arid zones, little is known about its genetic diversity in Chile. Only two studies on P. chilensis diversity have been reported so far; one describing $P$. chilensis diversity based on morphological traits (Contreras
1983), and a report focusing on the germination potential of individuals from different localities between $29^{\circ}$ and $33^{\circ} \mathrm{S}$ (Westphal et al. 2015). Taking into account that in Chile this species grows across the transverse valleys and considering that the degree of connectivity between natural populations depends on their dispersal capacity and the barriers imposed by the topography of the area (Sabando et al. 2011), the question that arises here is whether the genetic diversity and population structure of this species is determined by these mountain ridges in the Coquimbo Region. The spatial structuring imposed by the transverse valleys of the region on genetic variation has only been studied for two aquatic insect species so far (Sabando et al. 2011). The detected effects were inconsistent because the transverse mountain chains constituted a barrier for one of the species, but not for the other. To date, no study has investigated whether Chile's transverse valleys promote genetic isolation in plant populations, thus leading to their genetic diversification.

The aim of this study was therefore, to assess the genetic diversity and structure of natural populations of $P$. chilensis inhabiting the transverse valleys in north-central Chile belonging to the Coquimbo Region, in order to provide information for future conservation initiatives of this multiuse species. In view of the difficulties to describe diversity upon morphological traits for this genus (Saidman et al. 1998), we used nuclear and chloroplast microsatellite (SSR: Simple Sequence Repeats) markers to quantify and analyze genetic diversity. We hypothesized that the transversal valleys act as north-south physical barriers, affecting the genetic diversity and structure of $P$. chilensis. These geographical conditions could promote deviation from the Hardy-Weinberg equilibrium (HWE), leading to lower allelic diversity, lower heterozygosity, and increased genetic differentiation between the northern and southern populations of the Coquimbo Region.

\section{MATERIALS AND METHODS}

Study Site

The Coquimbo Region $\left(29^{\circ}-32^{\circ} \mathrm{S}\right)$ contains three main transversal valleys. It has a mediterranean-desertic and semi-desertic climate with a marked seasonality: rainfall in winter and 8-10 dry months per year (Novoa \& López 2001). The available weather information has indicated that average rainfall in La Serena city (29 54'S) has dropped about $100 \mathrm{~mm}(50 \%)$ in the last century (Squeo et al. 1999), placing it among those regions with the greatest decrease in precipitations worldwide (http://www.ipcc. $\mathrm{ch} /$ pub/tpbiodiv_s.pdf). These changes in precipitation coincided with increases of $0.6^{\circ} \mathrm{C}$ in the temperature of the Earth during the last century (http://www.ipcc.ch/pub/un/ ipccwg1s.pdf). The main transversal valleys (Elqui, Limarí and Choapa) have presented an increasing rainfall toward 
the South from approximately 60 to $300 \mathrm{~mm} \mathrm{a}^{-1}$; from Elqui to Choapa, respectively (Favier et al. 2009).

\section{SAMPLING AREA AND PLANT MATERIAL}

Prosopis chilensis populations were selected from the Elqui, Limarí and Choapa valleys (Fig. 1). Sixty to 70 leaf samples were collected across each valley (Table 1 and Table S1). All the samples were georeferenced with a GPS unit (Garmin, model eTrex Summit). When the sampled trees had flowers or buds, we collected some of these and prepared them as herbarium vouchers, which were deposited at the SGO Herbarium from the National Museum of Natural History in Santiago, Chile and ULS Herbarium from University of La Serena, Chile (Table S1).

Outgroups

Three Prosopis species were chosen as outgroups (Table $\mathrm{S} 1)$. Two leaf samples were taken from two individuals of Prosopis alba Griseb. and two individuals of Prosopis flexuosa DC. Individuals were sampled from populations growing in Quillagua (Antofagasta Region, $21^{\circ} \mathrm{S}$ ) and Donkey (Atacama Region, $28^{\circ} \mathrm{S}$ ), respectively. Additionally, we used leaves of two seedlings of Prosopis tamarugo Phil., germinated from seeds of natural populations from the Tarapacá Region $\left(20^{\circ} \mathrm{S}\right)$.

\section{DNA ISOLATION}

DNA was extracted from young expanding leaves according to Lodhi et al. (1994). The quality of the obtained DNA was evaluated on $0.8 \%$ agarose gels stained with ethidium bromide and DNA concentration was measured with a NanoDrop ND-1000 spectrophotometer (NanoDrop Technologies, Inc. Wilmington, DE, USA), according to the user's manual.
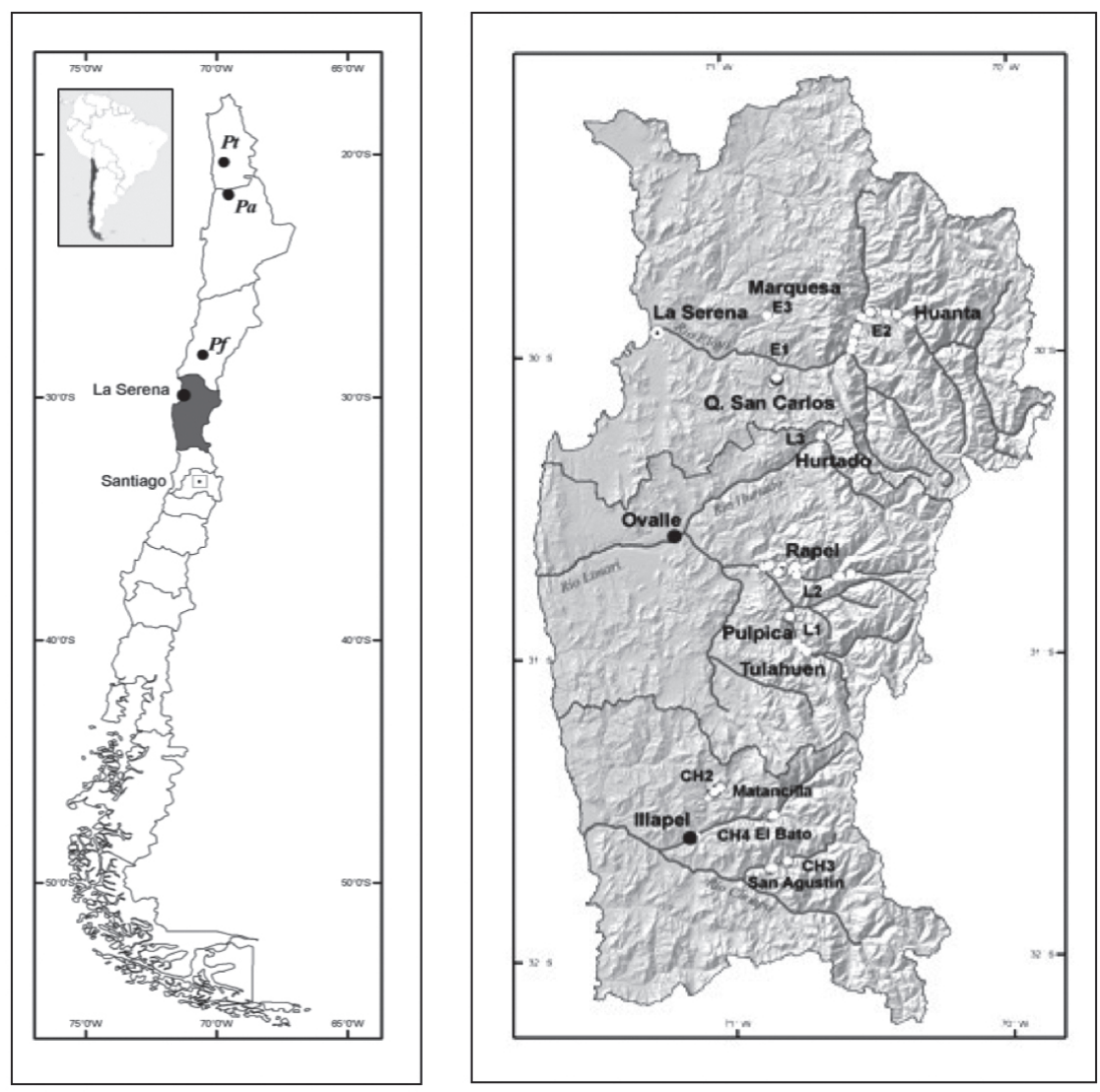

FIgURE 1. Location of the nine sampling sites of P. chilensis in the Coquimbo Region, Chile. The detailed map (right panel) shows the location of the three subpopulations studied from Elqui (E1, E2, E3), Limarí (L1, L2, L3) and Choapa (CH2, CH3, CH4) valleys. The river systems of these three valleys are indicated from North to South. Location of $P$. tamarugo $(P t), P$. alba $(P a)$ and $P$. flexuosa $(P f)$ outgroups are indicated in the left panel. (Inset map of South America was adapted from https://upload.wikimedia.org/wikipedia/commons/2/26/ Map_of_Chile_in_South_America.png)/Ubicación de los nueve sitios de muestreo de P. chilensis en la Región de Coquimbo, Chile. El mapa detallado (panel derecho) muestra la ubicación de las tres subpoblaciones estudiadas de los valles de Elqui (E1, E2, E3), Limarí (L1, L2, L3) y Choapa (CH2, CH3, CH4). Los ríos Elqui, Limarí y Choapa se indican de Norte a Sur. La ubicación de los grupos externos $P$. tamarugo $(P t), P$. alba $(P a)$ y $P$. flexuosa $(P f)$ se indica en el panel izquierdo. (Inserto de mapa de Sudamérica se adaptó de https://upload. wikimedia.org/wikipedia/commons/2/26/Map_of_Chile_in_South_America.png). 
TABLE 1. Summary of collected and analyzed P. chilensis samples from the Coquimbo Region, Chile, and their location in the three valleys / Resumen de las muestras recolectadas y analizadas de $P$. chilensis de la Región de Coquimbo, Chile, y su ubicación en los tres valles.

\begin{tabular}{lcc}
\hline VALLEY & $\begin{array}{c}\text { SAMPLED } \\
\text { TREES }\end{array}$ & $\begin{array}{c}\text { ANALYZED } \\
\text { TREES }\end{array}$ \\
\hline Elqui & 67 & 65 \\
Limarí & 70 & 64 \\
Choapa & 60 & 53 \\
\hline Total & 197 & 182 \\
\hline
\end{tabular}

NuCLEAR MICROSATELLITE ANALYSIS

Nuclear microsatellite markers have been developed for Prosopis using different strategies (Mottura et al. 2005, Bessega et al. 2013, Torales et al. 2013, Alves et al. 2014, Pomponio et al. 2015). This study was based on six nuclear microsatellite loci: Mo05, Mo07, Mo08, Mo09, Mo13, and Mo16, described for P. chilensis by Mottura et al. (2005). PCR reactions were performed using both unlabeled primers and labeled primers either with 6-FAM, HEX or NED fluorophores. Reactions were carried out on a mixture (15 $\mu$ l final volume) containing $10 \mathrm{ng}$ of DNA, $0.6 \mu \mathrm{M}$ of each primer, $150 \mu \mathrm{M}$ of each dNTP, $1.5 \mu \mathrm{l} 10 \mathrm{x}$ PCR buffer, $1.5 \mathrm{mM}$ of $\mathrm{MgCl}_{2}$ and $0.5 \mathrm{U} \mu \mathrm{l}$ of Taq DNA polymerase (Invitrogen) in a Techne TC-412 thermocycler (Barloworld Scientific Ltd., Staffordshire, UK). Amplification conditions were adjusted to an initial denaturation at $94^{\circ} \mathrm{C}$ for $5 \mathrm{~min}$, followed by 30 cycles of $45 \mathrm{~s}$ at $94{ }^{\circ} \mathrm{C}, 45 \mathrm{~s}$ at $59^{\circ} \mathrm{C}$ and 45 s at $72{ }^{\circ} \mathrm{C}$, and a final extension for $10 \mathrm{~min}$ at $72{ }^{\circ} \mathrm{C}$, before stopping the reaction.

Initial known allele sizes were determined using four external $P$. chilensis samples from an Algarrobo garden located at Antumapu Campus, University of Chile. For these samples, allele sizes were determined with an ABI310 automated sequencer equipped with GeneMapper ID v3.2 software (Applied Biosystems). Alleles were named according to their sizes in base pairs (bp), estimated with GeneScan-500 ROX size standard. The samples genotyped by capillary electrophoresis were used as standards in $6 \%$ denaturing polyacrylamide (PAA) sequencing gel electrophoresis, performed with PCR amplicons obtained with unlabeled primers and revealed by silver staining. Allele sizes were determined by visual comparison. Additional capillary electrophoreses were performed with samples displaying new alleles. At least two independent SSR reactions were conducted for each individual. PCR reactions for all outgroup samples were conducted as previously described.

\section{Chloroplast microsatellite analysis}

Universal chloroplast microsatellite loci have been used for genetic diversity studies (Provan et al. 2001). This study comprised the analysis of eight chloroplast microsatellite loci. Of these, six have been described as polymorphic for tobacco: ccmp2, ccmp3, ccmp5 (Weising \& Gardner 1999) and ccSSR9, ccSSR10, and ccSSR21 (Chung \& Staub 2003). Additionally, two microsatellite markers (RP19 and SOYCP) described as polymorphic for soybean were assayed (Powell et al. 1995).

For tobacco loci, PCR reactions were performed in a solution (final volume $15 \mu \mathrm{l}$ ) containing $10 \mathrm{ng}$ of DNA, 0.67 $\mu \mathrm{M}$ of each primer, $125 \mu \mathrm{M}$ of each dNTP, $1.5 \mu \mathrm{l} 10 \mathrm{x}$ PCR buffer, $2 \mathrm{mM}$ of $\mathrm{MgCl}_{2}$ and $0.5 \mathrm{U} \mu$ l of Taq DNA polymerase (Invitrogen) in a Techne TC-412 thermocycler (Barloworld Scientific Ltd., Staffordshire, UK). Amplification conditions were adjusted to an initial denaturation at $94{ }^{\circ} \mathrm{C}$ for $5 \mathrm{~min}$, followed by 30 cycles of $60 \mathrm{~s}$ at $94{ }^{\circ} \mathrm{C}, 60 \mathrm{~s}$ at $50^{\circ} \mathrm{C}$ and 60 s at $72{ }^{\circ} \mathrm{C}$, and a final extension for $8 \mathrm{~min}$ at $72{ }^{\circ} \mathrm{C}$, before stopping the reaction. For soybean loci, the PCR reaction mix was as described above. Amplification conditions were adjusted to an initial denaturation at $95{ }^{\circ} \mathrm{C}$ for $5 \mathrm{~min}$, followed by 30 cycles of $60 \mathrm{~s}$ at $94^{\circ} \mathrm{C}, 60 \mathrm{~s}$ at $55^{\circ} \mathrm{C}$ and 60 $\mathrm{s}$ at $72^{\circ} \mathrm{C}$, using the same final extension described.

Each locus was analyzed by denaturing $6 \%$ polyacrylamide sequencing gel electrophoresis and visualized by silver staining. Representative samples from each polymorphic haplotype detected were analyzed by capillary electrophoresis on an ABI310 sequencer as described above, using fluorophore-labeled primers in the PCR reaction. At least two independent SSR reactions were performed for each polymorphism detected. Alleles were named according to their size in base pairs (bp). PCR reactions for all outgroup samples were conducted as described. 
Genetic diversity of $P$. chilensis in the Coquimbo Region: Moncada, X. ET AL.

DATA SCORING AND GENETIC POPULATION ANALYSIS FOR NUCLEAR MICROSATELLITES

Alleles were manually recorded on the basis of the presence (1) or absence ( 0 ) of bands and assembled onto a data matrix. The effect of the sampled population size was evaluated from the empirical SSR data, constructing an allelic richness curve (number of alleles versus number of individuals) for each valley. Curves were constructed simulating repeated random subsampling from each valley to estimate the expected allelic richness captured with smaller population sizes (Leberg 2002) and analyzed using Statistica software v.8.0.5. Linkage disequilibrium was investigated by testing significance of the index of association, $I_{\mathrm{A}}$, and of its standardized alternative $\bar{r}_{d}$ proposed by Agapow \& Burt (2001), with 9,999 randomizations using the $\mathrm{R}$ package Poppr (Kamvar et al. 2014).

Population genetic structure and genetic diversity analyses of the nuclear microsatellite data were performed in $\mathrm{R}$ v. 3.3.1 ( $\mathrm{R}$ Core Team 2017). We investigated the existence of spatial genetic structure by means of a Mantel test (Mantel 1967) between Euclidean genetic and geographic distances, using the mantel.randtest function implemented in the package ade4 (Dray \& Dufour 2007) and 9,999 permutations. To identify possible spatial genetic clusters, we performed a spatial Principal Component Analysis (sPCA) (Jombart et al. 2008), as implemented in the adegenet package (Jombart 2008). sPCA is conceptually similar to traditional principal component analysis, but finds spatial principal components (PCs) that maximize spatial autocorrelation of the genetic data, instead of the variable correlations (Jombart et al. 2008). Spatial structure was modeled using a neighborhood by distance graph that considered $70 \mathrm{~km}$ as the maximum distance between any two connected neighbors. We defined the number of spatial PCs retained using the scree plot elbow rule. To understand the spatial structure described by the sPCA, we performed an UPGMA cluster analysis based on the Euclidean distances of the scores of the samples on the retained spatial PCs.

We tested the hierarchical population structure identified by the SPCA and partition genetic variance between the valleys by carrying out Analyses of Molecular Variance (AMOVA) implemented in the package Poppr (Kamvar et al. 2014). Both hierarchical and non-hierarchical analysis were performed. Separate non-hierarchical analyses were performed to test genetic differentiation between valleys and the uppermost hierarchical levels identified by the sPCA. The hierarchical analyses considered the genetic variation between clusters within the highest hierarchical levels as source of variation. Thus, they used the detected genetic clusters as sample units. Significance of the variance components associated with the different levels of genetic structure and their corresponding $\phi$ stratistics $\left(\phi_{S T}, \phi_{S C}, \phi_{C T}\right)$ (Cockerham \& Weir 1984) was evaluated with the randtest function of the ade4 package (Dray \& Dufour 2007) with
9,999 bootstrap replicates. Pairwise $F_{S T}$ values between the genetic clusters were calculated with the Hierfstat package (Goudet 2005) and tested with 9,999 permutations.

To assess genetic diversity within valleys, we used poppr and adegenet to calculate the expected heterozygosity $\left(H_{E}\right)$ and the rarefied allelic richness $\left(A_{R}\right)$, since they both account for unequal sample sizes values. Values for the allele frequencies were calculated and plotted using GenAlEx software 6.4 (Peakall \& Smouse 2006). The polymorphic information content (PIC) was calculated using Arlequin v.3.1.1 (Excoffier et al. 2005), as reported by Roussel et al. (2004). Microsatellite genotypes were tested for deviation from random mating by measuring departure from HWE within each valley at each locus, using the Arlequin 3.1.1 software (Excoffier et al. 2005).

\section{RESULTS}

\section{Chloroplast SSR}

From the eight SSR chloroplast markers tested, PCR products were obtained from ccmp2, ccmp3, ccmp5, ccSSR9, ccSSR10 and ccSSR21; however only the ccSSR10 marker presented polymorphisms. No amplification was obtained using the soybean cpSSR markers in P. chilensis samples (data not shown). For ccSSR10, five different haplotypes were found with 174, 175, 176, 177 and 178 bp. Haplotype 174 showed a slightly higher frequency in the Elqui and Limarí valleys than in the Choapa valley. Haplotype 175 was exclusive of the Elqui valley, while haplotype 176 was the most frequent in all three valleys. Haplotype 177, which is frequent in the Elqui valley, was less common in the Limarí and Choapa valleys, respectively. Haplotype 178 presented a much higher frequency in the Choapa valley than in the other two valleys. Haplotypes found in the outgroups $P$. alba, P. flexuosa and P. tamarugo, were 177, 176 and 174, respectively (See Table S3). Taken together, three of the five haplotypes found in $P$. chilensis presented different allelic distribution frequencies in the Choapa valley, compared to those found in the Elqui and Limarí valleys (Fig. 3 and Table S2), suggesting a different pattern within this valley.

NuClEAR SSR

Of the six nuclear SSR markers, two were discarded: Marker Mo07, which displayed profiles with three alleles and suffered amplification problems, and marker Mo16, which presented abundant stuttering and proved difficult to analyze by PAA gel electrophoresis. We successfully genotyped 182 samples for the remaining four nuclear SSR markers. No significant linkage disequilibrium was found, suggesting that the four nuclear markers were genetically independent $\left(I_{\mathrm{A}}=-0.05, P=0.9 ; \bar{r}_{d}=-0.02, P=0.9\right)$.

To assess whether the number of individuals analyzed was representative of the allelic richness from each valley, 
we constructed rarefaction curves of allelic richness (Fig. 2 ). In all three valleys, the rarefaction curves had reached the asymptote for sample sizes of 50, indicating that the number of individuals analyzed per valley (i.e. $>53$, Table 1) was adequate. The selected nuclear SSR markers displayed 28 alleles. They suggest moderate to high levels of genetic diversity. The number of alleles per loci ranged from 5 to 10 (Table 2) and the polymorphic information content (PIC) values ranged from 0.31 to 0.68 , with an average value of 0.5 (Table 2). The observed $\left(H_{O}\right)$ and expected $\left(H_{E}\right)$ heterozygosity varied between 0.17 and 0.77 and between 0.27 and 0.75 , respectively. In the Elqui and Choapa valleys, the average $H_{O}$ was significantly lower than expected under HWE $(P<0.05$, Table 3$)$. In the Limarí valley, $H_{O}$ was also lower than expected under HWE, but not significantly (Table 3 ).

While most alleles were present in all three valleys (i.e., 13), eight private alleles were detected: two in Elqui, one in Limarí, and five in Choapa. This suggests a higher allelic diversity within the southernmost valley. The rarefaction curves of allelic richness (Fig. 2), the total number of alleles, the rarefied allelic richness and expected heterozygosity provided consistent results; as in all cases, the lowest and highest genetic diversity estimates were found for the Elqui and Choapa valleys, respectively (Table 3 ).

Prosopis chilensis data shared only few alleles with the outgroup species used in this study. The four nuclear SSR markers amplified the outgroup species $P$. alba and $P$. flexuosa, but not $P$. tamarugo (Table S3). In $P$. alba and $P$. flexuosa, the Mo05 marker displayed alleles 215 and 216, while Mo08 exhibited alleles 212 and 220 for P. alba, and 210 and 214 for $P$.flexuosa. All these alleles were also present in $P$. chilensis samples. In the outgroup species, some alleles

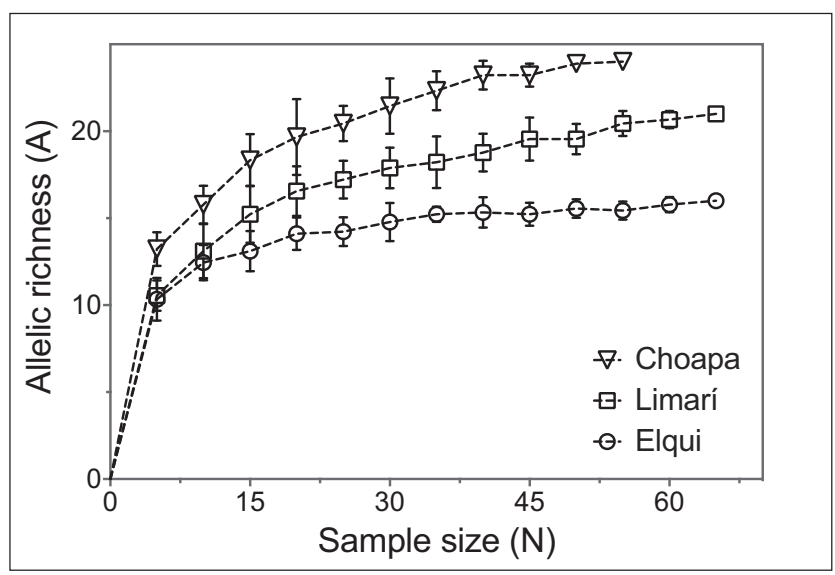

FIGURE 2. Allelic richness predicted by SSR data of $P$. chilensis individuals belonging to the three valleys of the Coquimbo Region, Chile. / Riqueza alélica predicha con los datos de SSR de los individuos de P. chilensis provenientes de la Región de Coquimbo, Chile. found for markers Mo09 and Mo13 were different from those found in P. chilensis: P. flexuosa presented alleles 214, 219 and 227, while $P$. alba presented alleles 214, 227 and 231, using the Mo09 marker. From these, alleles 219, 227 and 231 were not found in $P$. chilensis. Allele 214 was shared with $P$. chilensis, although it was found only at low frequency in the Limarí valley. Using Mo13, $P$. alba displayed alleles 232, 236 and 240. Allele 232 was not present in the P. chilensis samples; allele 236 was found only at low frequency in one valley (Elqui), whereas allele 240 was found in $P$. chilensis at low frequency in the three valleys. P. flexuosa presented a single allele 232, using the Mo13 marker. Both P. tamarugo samples analyzed in this work solely amplified the SSR Mo08 marker displaying alleles 214 and 215, which were also present in $P$. chilensis.

\section{Population STRUCTURE}

The sPCA identified only positively autocorrelated spatial patterns. The first two spatial PCs accounted for $93 \%$ of the positive autocorrelation ( 65 and $28 \%$ for $\mathrm{sPC} 1$ and $\mathrm{sPC} 2$, respectively). They revealed a three-level hierarchical structure (Fig. 4A). The uppermost hierarchical level separated individuals from the north and south of the study area, grouping together individuals from the Elqui and the north of the Limarí valleys on one hand, and individuals sampled from the Choapa and the south of the Limari valleys, on the other hand (Fig. 4B). The second hierarchical level further sub-divided these two groups, and isolated a group of individuals from the Elqui valley and some from the south of the Choapa valley (Fig. 4C). The third hierarchical level led to seven distinct genetic clusters. None of them overlapped between valleys. Within each valley, a northern and southern group was discerned, and in the case of the Limarí valley, a third group was formed, including the easternmost samples (Fig. 4D).

The results of the AMOVAs indicated that almost all genetic variation (i.e., about 94\%) was found between individuals within genetic clusters $\left(\phi_{S T}\right.$ range $=0.057-$ $0.147, \mathrm{P}<0.001$, Table 4). The upper hierarchical groups (e.g., the valley or groups identified by sPCA) show significant differentiation when tested individually, but not with hierarchical testing; that is, when the variation between the genetic clusters within the hierarchical groups was taken into account (Table 5). Even though the variation between the genetic clusters only accounted for $6.2-6.8 \%$ of the total genetic variation $\left(\phi_{S T}\right.$ range $=0.062-0.130, \mathrm{P}<0.001$, Table 4), it was still significant. The results of the genetic differentiation estimates show similar trends: while the pairwise $F_{S T}$ were low overall; ranging from 0.007 to 0.053 , all the genetic clusters were significantly differentiated from at least another cluster (Table 5). The Mantel test demonstrated that genetic differentiation increased as geographic distances increased. However, the detected correlation was low $\left(r_{M}=0.11, P<0.001\right)$. 
Genetic diversity of $P$. chilensis in the Coquimbo Region: Moncada, X. ET AL.

TABLE 2. Microsatellite alleles and PIC values for P. chilensis found in this study and in Mottura et al. (2005). / Alelos de microsatélites y valores de PIC encontrados para P. chilensis en este estudio y en Mottura et al. (2005).

\begin{tabular}{|c|c|c|c|c|c|c|}
\hline & \multirow[t]{2}{*}{$\mathrm{N}^{\circ}$} & \multicolumn{4}{|c|}{ OBSERVED ALLELE SIZE RANGE (bp) } & \multirow[t]{2}{*}{ Publication } \\
\hline & & Mo05 & $\mathrm{Mo08}$ & Mo09 & Mo13 & \\
\hline $\begin{array}{l}\text { Chile } \\
\text { (Coquimbo Region) }\end{array}$ & & $204-216$ & $210-222$ & $208-217$ & $216-240$ & \\
\hline Allele number & 182 & 5 & 10 & 5 & 8 & This study \\
\hline PIC & & 0.31 & 0.68 & 0.53 & 0.49 & \\
\hline Argentina & & $214-218$ & $208-222$ & $209-211$ & 218-246 & \\
\hline Allele number & 20 & 3 & 6 & 2 & 6 & MotTURA ET AL. 2005 \\
\hline PIC & & 0.49 & 0.48 & 0.14 & 0.66 & \\
\hline
\end{tabular}

$\mathrm{bp}=$ base pairs; PIC= Polymorphic Information Content. $/$ bp= pares de bases; PIC= Contenido de Información Polimórfica.

A
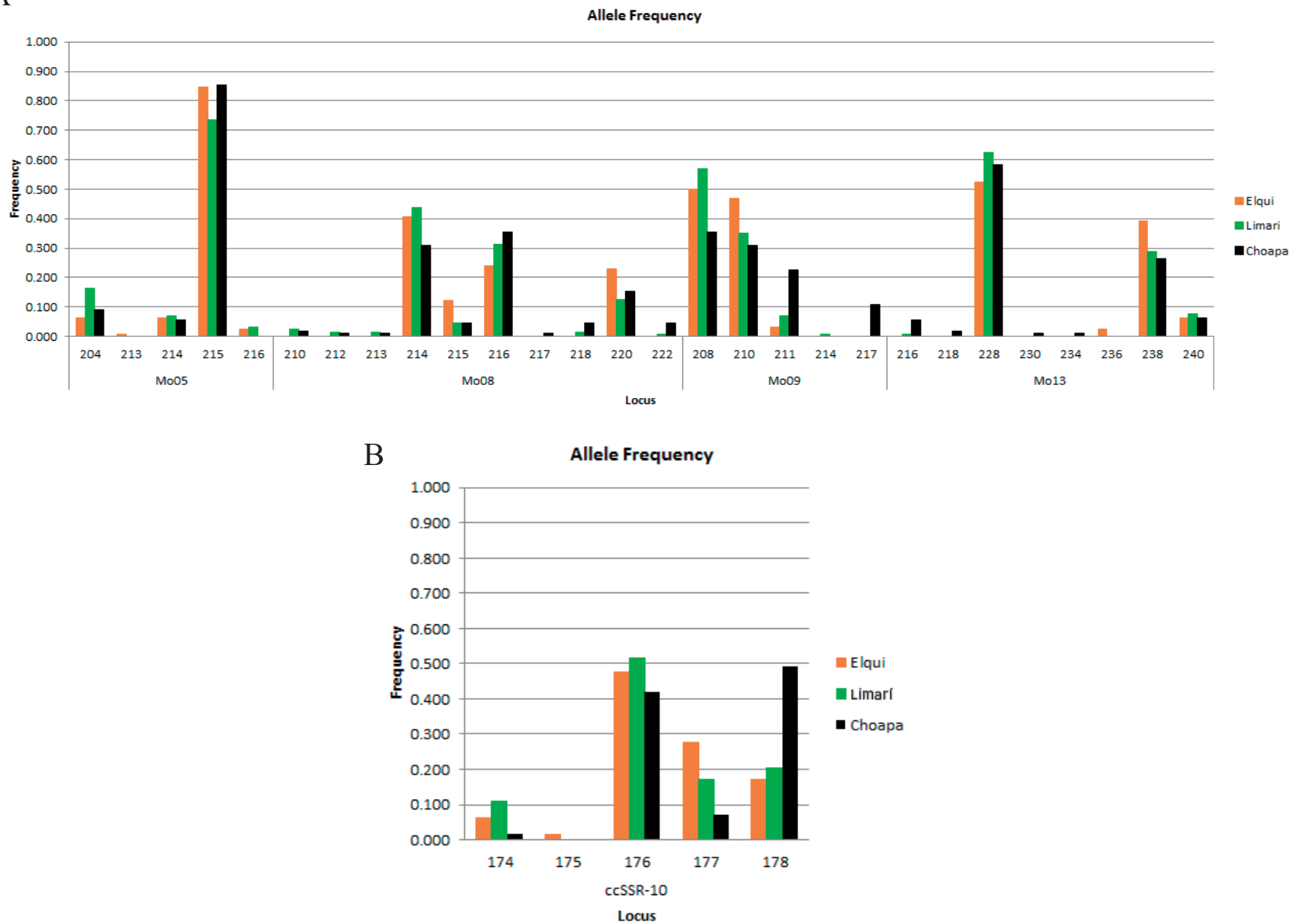

FIGURE 3. Allele frequency for $P$. chilensis from each valley of the Coquimbo Region, Chile. A: Nuclear SSR markers. B: Chloroplastic SSR markers. / Frecuencia alélica de P. chilensis para cada valle de la Región de Coquimbo, Chile. A: Marcadores nucleares de SSR. B: Marcadores cloroplásticos de SSR. 
Gayana Bot. 76(1), 2019

TABLE 3. Total number of alleles, rarefied allelic richness $\left(A_{R}\right)$, observed $\left(\mathrm{H}_{\mathrm{O}}\right)$ and expected $\left(\mathrm{H}_{\mathrm{E}}\right)$ heterozygosity found in P. chilensis. / Número total de alelos, riqueza alélica enrarecida $\left(A_{R}\right)$, heterocigosidad observada $\left(\mathrm{H}_{\mathrm{O}}\right)$ y esperada $\left(\mathrm{H}_{\mathrm{E}}\right)$ en $P$. chilensis.

\begin{tabular}{lccc}
\hline & ElQUi & LIMARí & CHOAPA \\
\hline Total number of alleles & 16 & 21 & 24 \\
Rarefied allelic richness $\left(A_{R}\right)$ & 15.55 & 19.57 & 22.63 \\
Ho $($ mean $\pm \mathrm{sd})$ & $0.44 \pm 0.23$ & $0.51 \pm 0.16$ & $0.49 \pm 0.24$ \\
He $($ mean $\pm \mathrm{sd})$ & $0.52 \pm 0.18$ & $0.55 \pm 0.11$ & $0.59 \pm 0.22$ \\
\hline
\end{tabular}

TABLE 4. Analyses of molecular variance (AMOVA) testing the hierarchical population structure identified by the spatial principal component analysis and the existence of genetic differentiation between the valleys. In both cases, the identified genetic clusters were used as the sampling unit. / Análisis de varianza molecular (AMOVA) de la estructura jerárquica de la población identificada por el análisis del componente principal espacial y la existencia de diferenciación genética entre los valles. En ambos casos, los grupos genéticos identificados se utilizaron como unidad de muestreo.

\begin{tabular}{|c|c|c|c|c|c|}
\hline SOURCE VARIATION & d.f. & SUM OF SQUARES & $\begin{array}{c}\text { Percentage } \\
\text { VARIATION }\end{array}$ & $\phi$ & $P$ \\
\hline \multicolumn{6}{|l|}{ Non-hierarchical AMOVAs } \\
\hline Between valleys & 2 & 10.21 & 2.76 & 0.028 & $<0.001$ \\
\hline Within valleys & 179 & 336.66 & 97.24 & & \\
\hline Between H1 & 1 & 3.60 & 0.96 & 0.010 & 0.03 \\
\hline Within H1 & 180 & 343.27 & 99.03 & & \\
\hline Between H2 & 3 & 11.04 & 2.60 & 0.025 & 0.05 \\
\hline Within $\mathrm{H} 2$ & 178 & 335.87 & 97.40 & & \\
\hline Between genetic clusters & 6 & 28.42 & 5.95 & 0.059 & $<0.001$ \\
\hline Within genetic clusters & 175 & 318.45 & 94.05 & & \\
\hline \multicolumn{6}{|l|}{$\underline{\text { Hierarchical AMOVAs }}$} \\
\hline Between valleys & 2 & 10.48 & -0.18 & 0.019 & 0.53 \\
\hline Between genetic clusters within valleys & 4 & 18.5 & 6.22 & 0.130 & $<0.001$ \\
\hline Within genetic clusters & 175 & 320.67 & 93.97 & 0.147 & $<0.001$ \\
\hline Between H1 & 1 & 3.99 & -0.91 & -0.009 & 0.32 \\
\hline Between $\mathrm{H} 2$ within $\mathrm{H} 1$ & 2 & 10.12 & -0.17 & -0.002 & 0.89 \\
\hline Between genetic clusters within $\mathrm{H} 2$ & 3 & 14.87 & 6.79 & 0.067 & $<0.001$ \\
\hline Within genetic clusters & 175 & 320.67 & 94.3 & 0.057 & $<0.001$ \\
\hline
\end{tabular}

d.f.: degrees of freedom. H1 and H2 refer to the groups identified by the spatial principal component analysis at first and second upper hierarchical level. / d.f: grados de libertad. $\mathrm{H} 1$ y H2 se refieren a los grupos identificados por el análisis espacial de componentes principales en el primer y segundo nivel jerárquico superior. 
Genetic diversity of $P$. chilensis in the Coquimbo Region: Moncada, X. ET AL.

TABLE 5. Pairwise $F_{S T}$ between the genetic clusters (above diagonal) identified by the spatial principal component analysis and their $\mathrm{P}$-values after false discovery rate correction (below diagonal). Values marked in bold were significantly different from 0 . / Parejas $\mathrm{F}_{S T}$ entre grupos genéticos (por encima de la diagonal) identificados por el análisis de componentes principales espaciales y sus valores $\mathrm{P}$ después de la corrección de falsa tasa de descubrimiento (por debajo de la diagonal). Los valores marcados en negrita fueron significativamente diferentes de 0 .

\begin{tabular}{cccccccc}
\hline & 1 & 2 & 3 & 4 & 5 & 6 & 7 \\
\hline 1 & & $\mathbf{0 . 0 3 5}$ & $\mathbf{0 . 0 5 3}$ & $\mathbf{0 . 0 2 5}$ & $\mathbf{0 . 0 2 7}$ & $\mathbf{0 . 0 3 2}$ & $\mathbf{0 . 0 4 8}$ \\
2 & 0.029 & & 0.016 & 0.011 & 0.016 & $\mathbf{0 . 0 2 7}$ & 0.035 \\
3 & 0.010 & 0.161 & & 0.022 & $\mathbf{0 . 0 3 1}$ & $\mathbf{0 . 0 4 2}$ & $\mathbf{0 . 0 5 2}$ \\
4 & 0.048 & 0.408 & 0.059 & & 0.007 & $\mathbf{0 . 0 2 6}$ & 0.010 \\
5 & 0.045 & 0.174 & 0.036 & 0.706 & & 0.027 & 0.014 \\
6 & 0.036 & 0.059 & 0.029 & 0.059 & 0.059 & & 0.039 \\
7 & 0.036 & 0.059 & 0.033 & 0.706 & 0.556 & 0.059 & \\
\hline
\end{tabular}

A

Cluster dendrogram of the SPCA scores

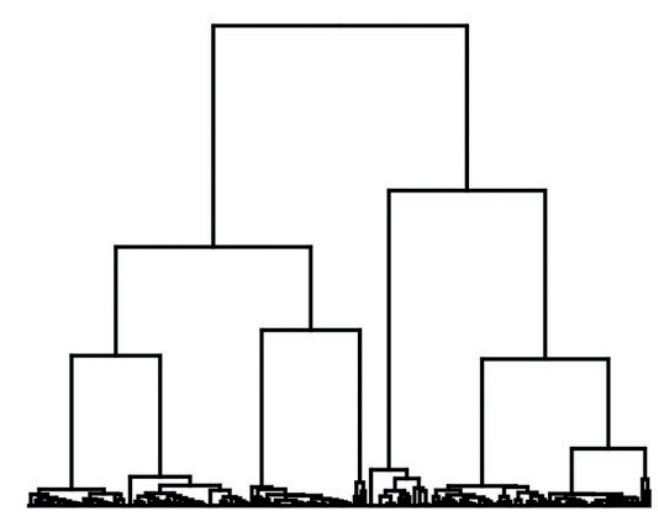

C

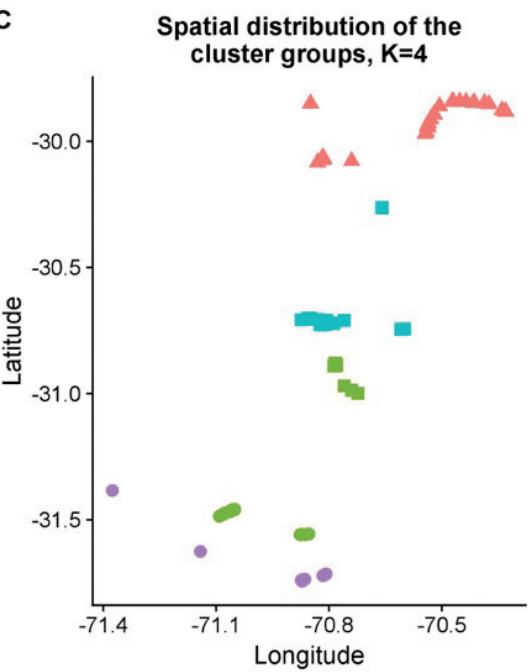

B
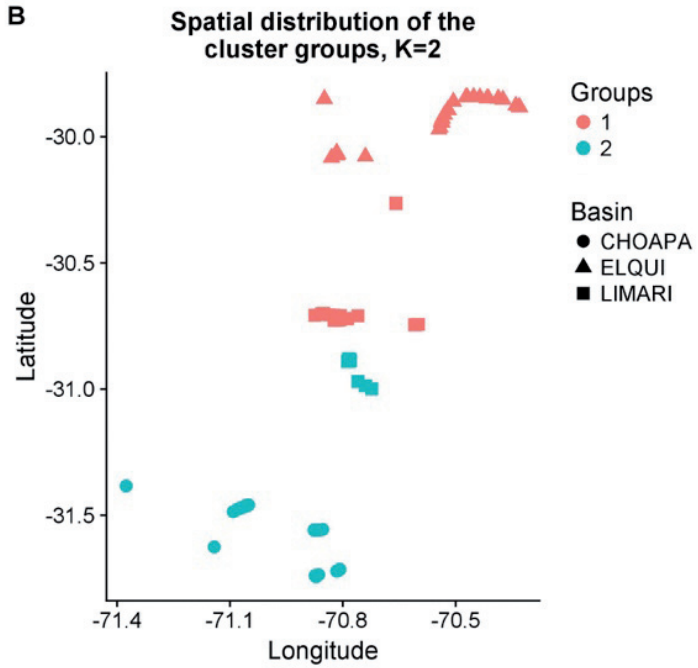

D

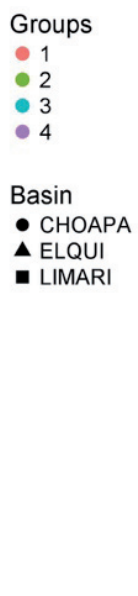

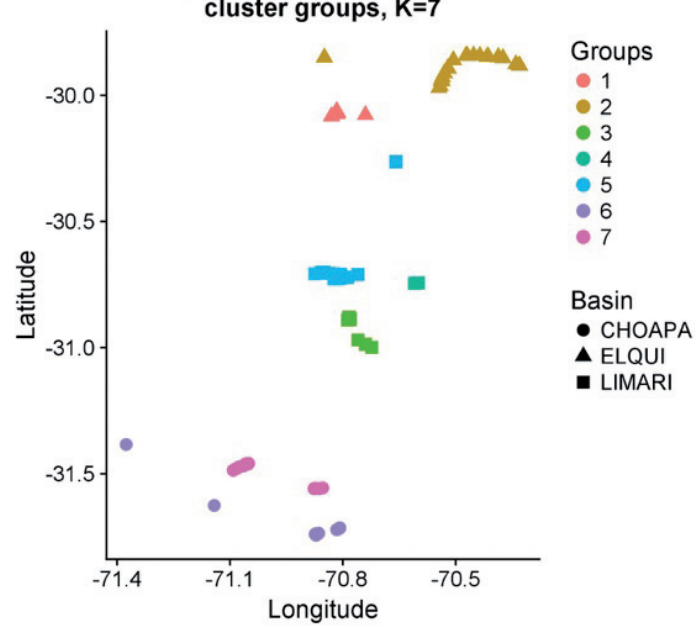

FIGURE 4. UPGMA cluster based on the Euclidean distances of the scores of the samples on the two first spatial principal components (A) and the spatial representation of the groups at the first (B), second (C) and third hierarchical levels (D). / UPGMA basado en las distancias euclidianas de las puntuaciones de las muestras en los dos primeros componentes espaciales (A) y la representación espacial de los grupos en el primer (B), segundo (C) y tercer nivel jerárquico (D). 


\section{DISCUSSION}

In this study we investigated the genetic diversity and structure of $P$. chilensis in three valleys of the Coquimbo Region of Chile: Elqui, Limarí, and Choapa. Our results suggest moderate to high levels of genetic diversity, since the average $H_{E}$ (i.e. >0.52) and PIC (average of 0.5) estimates were relatively high. Similar diversity levels have been reported for P. chilensis populations from Argentina, with PICs ranging from 0.14 to 0.66 and $H_{E}$ from 0.14 to 0.68 (Mottura et al. 2005). The number of alleles that we found with only four SSR for P. chilensis was higher than that reported by Mottura et al. (2005) in a study conducted using 20 samples of $P$. chilensis from Argentina (see Table 2). However, differences in sample sizes may explain this situation, since we analyzed a much higher number of individuals (i.e. $N=182$ ). A comparative study with a representative sample set using an enlarged set of SSR markers would be necessary to properly compare the genetic diversity and population structure of this species on both sides of the Andes. The genetic diversity estimates suggested higher levels of genetic diversity in the Choapa valley, the southernmost and most humid valley of the Coquimbo Region. In contrast, the lowest levels of genetic diversity were found in the Elqui valley, which corresponds to the northernmost and most arid valley.

Our analyses revealed weak population structure. While we did identify spatial genetic clusters, most of the genetic variation was found within them. This finding is relatively similar to the patterns described for $P$. chilensis in Argentina, and for P. cineraria (L.) Druce from different districts of Rajasthan (India). In both cases, much greater genetic variation was found within (i.e. 87-88\%), rather than between populations (12-13\%) (Ferreyra et al. 2004, Sharma et al. 2011). Sharma et al. (2011) attributed the observed pattern to elevated gene flows. The weak genetic differentiation and relatively high diversity genetic levels detected in our study suggest that gene flow is occurring across the Coquimbo Region. In spite of that, we detected a clear hierarchical genetic structure, which suggests that various structuring processes might be acting. At the uppermost hierarchical level, a northern and southern group were separated. This separation occurs at the level of the Limarí valley, in a region that has been described as a biogeographic transition zone (Squeo et al. 2001b, Hechem et al. 2011, Montecinos et al. 2012, Haye et al. 2014 ), and where abrupt and deep divergences have been reported in community composition of high Andean benthic macroinvertebrates (Bertin et al. 2015) and in population genetic structures in both coastal red algas (Montecinos et al. 2012) and a high Andean wetland plant (Troncoso et al. 2017). In the two latter cases, the genetic breaks were dated at more than 1 million years, suggesting that ancient regional events have driven the biological divergences observed in this region (Troncoso et al. 2017). While our AMOVA results demonstrated a significant differentiation between the northern and southern $P$. chilensis groups, the level of genetic variation explained was very low. This suggests that historical differentiation between the northern and southern groups may have existed, but might have been blurred by more recent gene flow. The proposed hypothesis of this work was that the transversal valleys of Elqui, Limarí and Choapa act as north-south barriers, affecting the genetic diversity and structure of $P$. chilensis. Our results partially support this hypothesis. None of the genetic clusters detected by the spatial analysis overlapped between the valleys. It is well known that valleys can isolate floras, as noted in the Andean dry valleys of southern Bolivia, at elevations between 1,300-3,200 m, displaying a high level of endemism ( $c a .18 \%$ of the species) (López 2003). Similarly, in central Chile, short-distance dispersed shrubs like Colliguaja odorifera Molina present genetic differences among the populations found on the slopes of the Coastal Range and the Andes between $32^{\circ}-34^{\circ} \mathrm{S}$, attributed to post-recent ice age dynamics (Bull-Hereñu et al. 2005). While we found that the inter-valley genetic differentiation of $P$. chilensis was significant, it accounted for very little of the genetic variation. This reveals that the mountain ridges separating the three transverse valleys either exerted a barrier effect in the past that has been almost entirely compensated by more recent gene flow, or that they just slightly hindered dispersal. In both cases, this would contrast with the strong valley effects usually reported in plant species that are wind-pollinated or that have wind-dispersed seeds (Tsuda et al. 2010). The high levels of genetic diversity observed within the valleys may be explained by the open pollination system, although some self-fertilization might have occurred (Bessega et al. 2000). While fruits and seeds of Prosopis are not adapted to long distance dispersion, effective endozoic dispersion can occur through mammals (wild and/or domestic) and birds (Burkart 1976a, b). In addition, and because of its importance as a food resource, seed transport by humans could also have contributed to gene flow between valleys in prehistoric times, and possibly, even during the recent past. McRostie et al. (2017) used archaeobotanical and palaeoecological records, as well as bibliographical reviews -including phylogenetic and taxonomic data- to evaluate the chronology of introduction and dispersal of Prosopis species belonging to Algarobia Section. They argued that these species are not native to the Atacama Desert of Chile $\left(18-27^{\circ} \mathrm{S}\right)$, appearing only in the late Holocene, and most likely due to human action. To date, there are no studies of archaeological remains of Prosopis from the Algarobia Section occurring in the Coquimbo Region, south to the Atacama Desert. Further studies would be needed to determine the origin of $P$. chilensis present south of the Atacama Desert, and to elucidate if its dispersal was 
determined by human and/or natural vectors.

Unexpectedly, we found that the highest genetic structure occurred within the valleys. Indeed, our sPCA analyses reveal the existence of seven distinct genetic clusters over the whole region; and while they accounted for little genetic variation, it was higher than that explained by the upper hierarchical levels. This indicates that the most structuring effects occurred at a more local scale. The clusters do not coincide with obvious orographic characteristics, suggesting that other local landscape features, such as human settlements, agricultures, etc., could be influencing the patterns of genetic diversity within and among the clusters. A more detailed landscape genetic study would be necessary to unravel these features.

In all three valleys, the average $H_{O}$ was lower than the average $H_{E}$, and this difference was significant in the Elqui and Choapa valleys. Such departures from HWE can result due to genetic erosion. The use of this species for firewood and the advancement of industrial agriculture strongly reduced $P$. chilensis populations (Arancio et al. 2001), leading to its current "vulnerable" conservation status (Squeo et al. 2001c, MMA, 2013). While such situations could cause genetic erosion, our genetic diversity estimates are still relatively high, suggesting that some other processes such as gene flow may compensate for the effects of population reductions on $P$. chilensis genetic diversity. Inbreeding is another mechanism that can lead to a deficit of heterozygotes. In a study of mating system parameters, Bessega et al. (2000) found that species of the genus Prosopis, including P. chilensis, mostly outcrossed, but that selfing occurred in some populations. The reported percentage for the studied $P$. chilensis population selfing ranged between 0.19 and 0.32 . Such selfing rates could explain the observed deficit of heterozygotes, which averaged $16 \%$ with all of the SSR markers studied.

The SSR chloroplast marker ccSSR10 was found to be highly polymorphic, but was not as informative as nuclear SSR markers for the populations analyzed in this study. As shown in Figure 3, this marker presented a haplotype distribution that is useful to characterize the genetic structure of $P$. chilensis. This chloroplast marker presented a specific allele pattern for the Choapa valley that did not reveal population structure, which is consistent with the weak structure detected by the nuclear SSR markers. To our knowledge, the eight chloroplast SSR markers tested in this work had not been used previously to characterize $P$. chilensis populations, although other chloroplast SSR markers from $P$. alba had been previously described (Torales et al. 2013). As chloroplast DNA is mainly maternally inherited, information from chloroplast microsatellites differs from that obtained from nuclear SSR because cytoplasmic genomes are inherited uniparentally in most angiosperms (Birky 1995). Interestingly, in spite of their differential inheritance, the results that we obtained were relatively consistent, showing a slight difference in samples from the Choapa valley in relation to those from the Elqui and Limarí valleys.

Physiological studies of $P$. chilensis also suggest high levels of diversity between individuals. Westphal (2016) studied salt stress tolerance in 12 populations selected along its Chilean distribution, finding that seedlings exhibit physiological differences among populations in almost all parameters evaluated. These differences did not correlate with the geographical gradient, which is consistent with the weak differentiation among populations found in this study.

This is the first study of the population structure of $P$. chilensis and indeed, of a species belonging to the Prosopis genus in Chile, using molecular markers. Our results suggest that the mountain ridges separating the three transverse valleys of the Coquimbo Region impose partial restrictions to gene flow among P. chilensis. In order to assess the complete genetic diversity and structure of $P$. chilensis across its complete range, further studies that include the Aconcagua and Maipo valleys -the southernmost distribution range in Chile- and on both sides of the Andes, are needed. The genetic data of this study and their integration with further physiological studies will provide a deeper understanding of this vulnerable multipurpose tree species.

\section{ACKNOWLEDGMENTS}

Supported by FONDECYT 3070003 and partially by ICM P05-002 and CONICYT PFB-23. We thank D. López, D. Díaz, A. Hueche and C. Trigo, for technical assistance; CONAF and INIA for field collections of outgroups; D. Carvajal for field assistance; Dr. M. Pinto for Antumapu P. chilensis samples; Dr. A. Maldonado for valuable field advices; Prof. S. Zepeda for facilities at ULS and PDI for EC analysis; A. Alvéstegui for suggestions and Dr. C. Lusk for valuable advice on this manuscript. We also thank two anonymous reviewers for valuable suggestions on the manuscript.

\section{SUPPLEMENTARY DATA}

- Supplementary file 1: Table S1: Complete number of $P$. chilensis individuals sampled and outgroup samples used, including their geographic location.

- Supplementary file 2: Table S2: Distribution frequency of alleles from each valley for nuclear and chloroplastic SSR markers.

- Supplementary file 3: Table S3: Alleles found in nuclear and chloroplast SSR markers in the outgroups used in this study: P. alba, P. flexuosa and P. tamarugo. 


\section{REFERENCES}

Agapow, P.-M., Burt, A. 2001. Indices of multilocus linkage disequilibrium. Molecular Ecology Resources 1(1-2): 101102.

Alves, F.M., Zucci, M.I., Azevedo-Tozzi, A.M., Sartori, A.L.B., SouzA, A.P. 2014. Characterization of microsatellite markers developed from Prosopis rubriflora and Prosopis ruscifolia (Leguminosae-Mimosoideae), legume species that are used as models for genetic diversity studies in Chaquenian areas under anthropization in South America. BMC Research Notes 7(1): 375.

Arancio, G., Muñoz, M., Squeo, F.A. 2001. Descripción de algunas especies con problemas de conservación en la IV Región de Coquimbo, Chile. En: Squeo, F.A., Arancio, G., Gutiérrez, J.R. (eds.), Libro rojo de la flora nativa y de los sitios prioritarios para su conservación: Región de Coquimbo, pp. 63-103. Ediciones Universidad de La Serena, La Serena, Chile.

Bertin, A., Alvarez, E., Gouin, N., Gianoli, E., Montecinos, S., Lek, S., Gascoin, S., Lhermitte, S. 2015. Effects of winddriven spatial structure and environmental heterogeneity on high-altitude wetland macroinvertebrate assemblages with contrasting dispersal modes. Freshwater Biology 60(2): 297-310

Bessega, C., Ferreyra, L., Julio, N., Montoya, S., Saidman, B., VILARDI, J.C. 2000. Mating system parameters in species of genus Prosopis (Leguminosae). Hereditas 132(1): 19-27.

Bessega, C.F., Pometti, C.L., Miller, J.T., Watts, R., Saidman, B.O., Vilardi, J.C. 2013. New Microsatellite loci for Prosopis alba and P. chilensis (Fabaceae). Applications in Plant Sciences 1(5): 1200324. http://dx.doi.org/10.3732/ apps. 1200324.

BIRKY, C.W. JR. 1995. Uniparental inheritance of mitochondrial and chloroplast genes: mechanisms and evolution. Proceedings of the National Academy of Sciences of USA 92(25): 11331-11338.

Burkart, A. 1976a. A Monograph of the genus Prosopis (Leguminosae subfam. Mimosoideae). Journal of the Arnold Arboretum 57(3): 219-249.

Burkart, A. 1976b. A Monograph of the genus Prosopis (Leguminosae subfam. Mimosoideae). Catalogue of the recognized species of Prosopis. Journal of the Arnold Arboretum 57(4): 450-525.

Bull-Hereñu, K., Martínez, E.A., Squeo, F.A. 2005. Structure and genetic diversity in Colliguaja odorifera Mol. (Euphorbiaceae), a shrub subjected to pleisto-holocene natural perturbations in a Mediterranean South America region. Journal of Biogeography 32(7): 1129-1138.

Chung, S., Staub, J.E. 2003. The development and evaluation of consensus chloroplast primer pairs that possess highly variable sequence in a diverse array of plant taxa. Theoretical and Applied Genetics 107(4): 757-767.

Cockerham, C.C., Weir, B.S. 1984. Covariances of relatives stemming from a population undergoing mixed self and random mating. Biometrics 40(1): 157-164.

Contreras, B.E. 1983. Diversidad morfológica en poblaciones de algarrobo (Prosopis chilensis (Mol.) Stuntz) en la IV Región. Tesis Ingeniería Forestal. Facultad de Ciencias Forestales. Universidad de Chile. Santiago, Chile. 108 pp.
Dray, S., Dufour, A.B. 2007. The ade4 package: implementing the duality diagram for ecologists. Journal of Statistical Software 22(4): 1-20.

Excoffier, L., LaVal, G., Schneider, S. 2005. Arlequin version 3.1: An integrated software package for population genetics data analysis. Evolutionary Bioinformatics Online 1: 4750 .

Errázuriz, A.M., Cereceda, P., GonzÁlez, J.I., GonzÁlez, M., Henríquez, M., Rioseco, R. 1998. Manual de Geografía de Chile. Andrés Bello, Santiago de Chile. 437 pp.

Farías, M., Charrier, R., Carretier, S., Martinod, J., Fock, A., Campbell, D., CÁceres, J., Comte, D. 2008. Late Miocene high and rapid surface uplift and its erosional response in the Andes of central Chile (338-358S). Tectonics 27(1), TC1005. doi:10.1029/2006TC002046.

Favier, V., Falvey, M., Rabatel, A., Praderio, E., López, D. 2009. Interpreting discrepancies between discharge and precipitation in high-altitude area of Chile's Norte Chico region (26-32 S). Water Resource Research 45(2): W02424. doi:10.1029/2008WR006802.

Ferreyra, L.I., Bessega, C., Vilardi, J.C., Saidman, B.O. 2004. First report on RAPDs patterns able to differentiate some Argentinean species of section Algarobia (Prosopis, Leguminosae). Genetica 121(1): 33-42.

Ferreyra, L.I., Vilardi, J.C., Tosto, D.C., Julio, N.B., Saidman, B.O. 2010. Adaptative genetic diversity and population structure of the "algarrobo" [Prosopis chilensis (Molina) Stuntz] analysed by RAPD and isozymes markers. European Journal of Forest Research 129(6): 1011-1025.

Galera, F.M. 2000. Los Algarrobos. Las especies del género Prosopis (algarrobos) de América Latina con especial énfasis en aquellas de interés económico. 276 pp. http:// www.fao.org/docrep/006/ad314s/ad314s00.htm.

Goudet, J. 2005. Hierfstat, a package for R to compute and test hierarchical F-statistics. Molecular Ecology Resources 5(1): 184-186.

Haye, P.A., Segovia, N.I., Muñoz-Herrera, N.C., Gálvez, F.R., Martínez, A., Meynard, A., Pardo-Gandarillas, M.C., Poulin, E., Faugeron, S. 2014. Phylogeographic structure in benthic marine invertebrates of the Southeast Pacific Coast of Chile with differing dispersal potential. PLoS One 9(2):e88613. https://doi.org/10.1371/journal. pone. 0088613

Hechem, V., Acheritobehere, L., Morrone, J.J. 2011. Patrones de distribución de las especies de Cynanchum, Diplolepis y Tweedia (Apocynaceae: Asclepiadoideae) de América del Sur austral. Revista de Geografía Norte Grande 48: 45-60. https://dx.doi.org/10.4067/S0718-34022011000100004

Hunziker, J.H., Saidman, B.O., Naranjo, C.A., Palacios, R.A., Poggio, L., Burghardt, A.D. 1986. Hybridization and genetic variation of Argentine species of Prosopis. Forest Ecology and Management 16(1-4): 301-315.

Jombart, T. 2008. Adegenet: a R package for the multivariate analysis of genetic markers. Bioinformatics 24(11): 14031405.

Jombart, T., Devillard, S., Dufour, A.B., Pontier, D. 2008. Revealing cryptic spatial patterns in genetic variability by a new multivariate method. Heredity 101(1): 92-103.

Kamvar, Z.N., Tabima, J.F., Grünwald, N.J. 2014. Poppr: an R package for genetic analysis of populations with clonal, 
Genetic diversity of $P$. chilensis in the Coquimbo Region: MoncadA, X. ET AL.

partially clonal, and/or sexual reproduction. PeerJ 2: e281. https://doi.org/10.7717/peerj.281

Leberg, P.L. 2002. Estimating allelic richness: Effects of sample size. Molecular Ecology 11(11): 2445-2449.

Lodhi, M.A., Ye, G., Weeden, N.F., Reisch, B.I. 1994. A simple and efficient method for DNA extraction from grapevine cultivars and Vitis species. Plant Molecular Biology Reporter 12(1): 6-13.

LóPEZ, R.P. 2003. Phytogeographical relations of the Andean dry valleys of Bolivia. Journal of Biogeography 30(11): 16591668 .

Mantel, N. 1967. The detection of disease clustering and a generalized regression approach. Cancer Research 27(2): 209-220.

McRostie, V.B., Gayo, E.M., Santoro, C.M., De Pol-Holz, R., LATORRE, C. 2017. The pre-Columbian introduction and dispersal of Algarrobo (Prosopis, Section Algarobia) in the Atacama Desert of northern Chile. PLoS ONE 12(7): e0181759

MMA. 2013. Decreto Supremo No 13/2013 del Ministerio del Medio Ambiente: Aprueba y oficializa clasificación de especies según su estado de conservación, noveno proceso. Publicado en el Diario Oficial de la República de Chile, 25 de julio de 2013.

Montecinos, A., Broitman, B.R., Faugeron, S., Haye, P., Tellier, F., Guillemin, M.-L. 2012. Species replacement along a linear coastal habitat: phylogeography and speciation in the red alga Mazzaella laminarioides along the southeast pacific. BMC Evolutionary Biology 12(1): 97.

Mottura, M.C., Finkeldey, R., Verga, A.R., Gailing, O. 2005. Development and characterization of microsatellite markers for Prosopis chilensis and Prosopis flexuosa and cross-species amplification. Molecular Ecology Resources 5(3): 487-489.

NovoA, J.E., López, D. 2001. IV Región: El escenario geográfico físico. En: Squeo, F.A., Arancio, G., Gutiérrez, J.R. (eds.), Libro rojo de la flora nativa y de los sitios prioritarios para su conservación: Región de Coquimbo, pp 13-22. Ediciones Universidad de La Serena, La Serena, Chile.

Pasiecznik, N.M., Felker, P., Harris, P.J.C., Harsh, L.N., Cruz, G., Tewari, J.C., Cadoret, K., Maldonado, L.J. 2001. The Prosopis juliflora-Prosopis pallida Complex: A Monograph. HDRA, Coventry. 172 pp.

Peakall, R., Smouse, P.E. 2006. GENALEX 6: genetic analysis in Excel. Population genetic software for teaching and research. Molecular Ecology Resources 6(1): 288-295.

Pomponio, M.F., Acuña, C., Pentreath, V., Lauenstein, D.L., Poltri, S.M., Torales, S. 2015. Characterization of functional SSR markers in Prosopis alba and their transferability across Prosopis species. Forest Systems 24(2): eRC04.

Powell, W., Morgante, M., McNicol, J.W., Machray, G.C., Doyle, J.J., Tingey, S.Y., Rafalski, A.J. 1995. Hypervariable microsatellites provide a general source of polymorphic DNA markers for the chloroplast genome. Current Biology 5(9): 1023-1029.

Provan, J., Powell, W., Hollingsworth, P.M. 2001. Chloroplast microsatellites: new tools for studies in plant ecology and evolution. Trends in Ecology and Evolution 16(3): 142147.
R Core Team. 2017. R: A Language and Environment for Statistical Computing. R Foundation for Statistical Computing, Vienna, Austria. URL: https://www.R-project.org.

Roussel, V., Koenig, J., Bechert, M., Balfourier, F. 2004. Molecular diversity in French bread wheat accessions related to temporal trends and breeding programmes. Theoretical and Applied Genetics 108(5): 920-930.

Sabando, M.C., Vila, I., Peñaloza, R., Véliz, D. 2011. Contrasting population genetic structure of two widespread aquatic insects in the Chilean high-slope rivers. Marine and Freshwater Research 62(1): 1-10.

Saidman, B.O., Vilardi, J.C., Montoya, S., Dieguez, M.J., Hopp, H.E. 1998. Molecular markers: A tool for the understanding of the relationships among species of Prosopis (Leguminosae, Mimosoidae). In: PuRI, S. (ed.), Tree Improvement: Applied Research and Technology Transfer, pp 311-324. Science Publishers Inc., USA.

Sharma, S.K., Kumar, S., Rawat, D., Kumaria, S., Kumar, A., RaO, S.R. 2011. Genetic diversity and gene flow estimation in Prosopis cineraria (L.) Druce: a key stone tree species of Indian Thar Desert. Biochemical Systematics and Ecology 39(1): 9-13.

Squeo, F.A., Arancio, G., Gutiérrez, J.R. 2001a. Libro Rojo de la Flora de la Región de Coquimbo, y de los Sitios Prioritarios para su Conservación. Ediciones Universidad de La Serena, La Serena. 386 pp.

Squeo, F.A., Arancio, G., Cavieres, L. 2001b. Definición conceptual y descripción de la metodología para definir el estado de conservación de la flora nativa de la IV Región de Coquimbo. En: Squeo, F.A., Arancio, G., Gutiérrez, J.R. (eds.), Libro rojo de la flora nativa y de los sitios prioritarios para su conservación: Región de Coquimbo, pp. 31-40. Ediciones Universidad de La Serena, La Serena, Chile.

Squeo, F.A., Arancio, G., Cavieres, L., Gutiérrez, J.R., Muñoz, M., Marticorena, C. 2001c. Análisis del estado de conservación de la flora nativa de la IV Región de Coquimbo. En: Squeo, F.A., Arancio, G., Gutiérrez, J.R. (eds.), Libro rojo de la flora nativa y de los sitios prioritarios para su conservación: Región de Coquimbo, pp. 53-62. Ediciones Universidad de La Serena, La Serena, Chile.

Squeo, F., Olivares, N., Olivares, S., Pollastri, A., Aguirre, E., Aravena, R., Jorquera, C., Ehleringer, J.R. 1999. Grupos funcionales en arbustos desérticos definidos en base a las fuentes de agua utilizadas. Gayana Botánica 56(1): 1-15.

Torales, S., M.L. Rivarola, M.F. Pomponio, S. González, C.V. Acuña, P. Fernández, Lauenstein, D.L., Verga, A., Hopp, E.H., Paniego, N.B., Marcucci Poltri, S.N. 2013. De novo assembly and characterization of leaf transcriptome for the development of functional molecular markers of the extremophile multipurpose tree species Prosopis alba. Bmc Genomics 14(1): 705.

Troncoso, A.J., Bertin, A., Osorio, R., Arancio, G., Gouin, N. 2017. Comparative population genetics of two dominant plant species of high Andean wetlands reveals complex evolutionary histories and conservation perspectives in Chile's Norte Chico. Conservation Genetics 18(5): 10471060 . 
Tsuda, Y., Sawada, H., Ohsawa, T., Nakao, K., Nishikawa, H., IDE, Y. 2010. Landscape genetic structure of Betula maximowicziana in the Chichibu mountain range, central Japan. Tree Genetics and Genomes 6(3): 377-387.

Verzino, G., Carranza, C., Ledesma, M., Joseau, J., Di Rienzo, J. 2003. Adaptative genetic variation of Prosopis chilensis (Mol) Stuntz. Preliminary results from one test-site. Forest Ecology and Management 175(1-3): 119-129.

Villagrán, C., Hinojosa, L.F. 1997. Historia de los bosques del sur de Sudamérica II: Análisis fitogeográfico. Revista Chilena de Historia Natural 70(2): 241-267.

Weising, K., Gardner, R. 1999. A set of conserved PCR primers for the analysis of simple sequence repeat polymorphisms in chloroplast genomes of dicotyledonous angiosperms. Genome 42(1): 9-19.

Westrhal, C., Gachón, P., Bravo, J., Navarrete, C., Salas, C., IBÁÑEZ, C. 2015. The Potential of Algarrobo (Prosopis chilensis (Mol.) Stuntz) for Regeneration of Desertified Soils: Assessing Seed Germination Under Saline Conditions. Environmental Management 56(1): 209-220.

Westphal, C. 2016. Desde la semilla al gen: investigando la tolerancia al estrés salino en Prosopis chilensis (Mol.) Stuntz. Tesis Doctoral. Biología y Ecología Aplicada, Universidad de La Serena y Universidad Católica del Norte. La Serena, Chile. 163 pp.

Wright, S. 1943. Isolation by distance. Genetics 28(2): 114-138.

Recibido: 31.08 .2016

Aceptado: 25.09 .2018 